\title{
Synthesis of Purines and Other Fused Imidazoles from Acyclic Amidines and Guanidines
}

Bruce G. Szczepankiewicz, Jeffrey J. Rohde, Ravi Kurukulasuriya

Supporting InformationGeneral: Starting materials were purchased from commercial suppliers and were used without further purification. Microwave heating was performed using a Personal Chemistry Emrys Optimizer microwave apparatus with temperature monitoring via IR sensor. TLC solvent systems were the same as those used for flash chromatography, with $\mathrm{R}_{\mathrm{f}}=c a .0 .25$. In some cases, reactions were monitored by reversed-phase HPLC using a C-18 column and eluting with a gradient of 0 to $100 \%$ $\mathrm{CH}_{3} \mathrm{CN}$ in $0.1 \%$ aq. TFA. Melting points were determined using a Thomas Hoover melting point apparatus and are uncorrected. NMR data are reported in units of ppm with the following abbreviations: s-singlet, d-doublet, t-triplet, m-multiplet, b-broad. Combustion analyses were performed by Quantitative Technologies Inc., Whitehouse NJ.<smiles>CC(C)(C)OC(=O)NC1CCCN(C(N)=[NH2+])C1</smiles>

(1-Carbamimidoyl-piperidin-3-yl)-carbamic acid tert-butyl ester hydrochloride. (1) To a solution of $984 \mathrm{mg}(5.34 \mathrm{mmol})$ of piperidin-3-yl-carbamic acid tert-butyl ester in $2.7 \mathrm{~mL}$ of DMF was added $783 \mathrm{mg}$ (5.34 mmol) of pyrazole-1-carboxamidine hydrochloride, ${ }^{1}$ and $930 \mu \mathrm{L}(5.34 \mathrm{mmol})$ of $N, N$-diisopropylethylamine. The reaction was stirred at ambient temperature for $96 \mathrm{~h}$, then diluted with $50 \mathrm{~mL}$ of diethyl ether. The mixture was stirred for $2 \mathrm{~h}$, then the solvents were decanted to leave an oil. This was taken up in $2 \mathrm{~mL}$ of ethanol, then the solution was diluted with $25 \mathrm{~mL}$ of ethyl acetate and $10 \mathrm{~mL}$ of hexanes. The solvents were decanted, and the residue was dried in vacuo to give $1.24 \mathrm{~g}$ of a white foam. An additional $140 \mathrm{mg}$ of product crystallized from the ethyl acetate mixture for a total yield of $93 \%$. mp $165-166^{\circ} \mathrm{C}$ (with bubbling). ${ }^{1} \mathrm{H}$ NMR $\left(300 \mathrm{MHz}, \mathrm{DMSO}-d_{6}\right) \delta 7.41(\mathrm{~s}, 4 \mathrm{H}), 7.03(\mathrm{~d}, J=7.5 \mathrm{~Hz}, 1 \mathrm{H}), 3.64(\mathrm{~m}, 2 \mathrm{H}), 3.34(\mathrm{~m}, 1$ $\mathrm{H}), 2.96(\mathrm{~m}, 2 \mathrm{H}), 1.77(\mathrm{~m}, 2 \mathrm{H}), 1.39(\mathrm{~s}, 9 \mathrm{H}), 1.43(\mathrm{~m}, 2 \mathrm{H}) ; \mathrm{MS}(\mathrm{ESI})^{+} \mathrm{m} / z=243$ $(\mathrm{M}+\mathrm{H})^{+}$. Anal. Calc'd for $\mathrm{C}_{11} \mathrm{H}_{23} \mathrm{ClN}_{4} \mathrm{O}_{2}$ : C, 47.39; H, 8.32; N, 20.10. Found: C, 47.42, $\mathrm{H}, 8.60, \mathrm{~N}, 19.97$.<smiles>COc1c(Br)c(=O)n(C)c(=O)n1C</smiles>

5-Bromo-6-methoxy-1,3-dimethyl-1H-pyrimidine-2,4-dione. (2) To an ice cooled solution of $1.56 \mathrm{~g}(10.0 \mathrm{mmol})$ of 1,3-dimethylbarbituric acid in $50 \mathrm{~mL}$ of ethyl acetate and $10 \mathrm{~mL}$ of methanol was added $8 \mathrm{~mL}$ of $2.0 \mathrm{M}$ trimethylsilyldiazomethane in diethyl 
ether. The reaction was stirred for $10 \mathrm{~min}$, then concentrated in vacuo to a solid. This was taken up in $25 \mathrm{~mL}$ of $\mathrm{CH}_{2} \mathrm{Cl}_{2}$ and cooled with an ice bath, then $1.77 \mathrm{~g}(10.0 \mathrm{mmol})$ of $\mathrm{N}$-bromosuccinimide was added. The mixture was stirred at $0{ }^{\circ} \mathrm{C}$ for $10 \mathrm{~min}$, then concentrated to a solid. This was taken up in $50 \mathrm{~mL}$ of ethyl acetate and extracted with water $(2 \times 15 \mathrm{~mL})$, then brine $(1 \times 15 \mathrm{~mL})$, dried over $\mathrm{MgSO}_{4}$, filtered, and concentrated to a solid. The product was purified via silica gel chromatography, eluting with 1: 1 ethyl acetate: hexanes to give $1.80 \mathrm{~g} \mathrm{(72 \% )}$ of a white solid. The product can also be recrystallized from ethyl acetate. The material was best used for subsequent reactions on the same day. mp 109-110 ${ }^{\circ} \mathrm{C} .{ }^{1} \mathrm{H}$ NMR (300 MHz, DMSO- $\left.d_{6}\right) \delta 4.01$ (s, $3 \mathrm{H}$ ), 3.30 (s, 3 $\mathrm{H}), 3.21(\mathrm{~s}, 3 \mathrm{H})$; MS $(\mathrm{ESI})^{+} \mathrm{m} / \mathrm{z}=249(\mathrm{M}+\mathrm{H})^{+}, 251(\mathrm{M}+\mathrm{H})^{+}$. Anal. Calc'd for $\mathrm{C}_{7} \mathrm{H}_{9} \mathrm{BrN}_{2} \mathrm{O}_{3}$ : C, 33.76; H, 3.64; N, 11.25. Found: C, 33.66; H, 3.36; N, 11.11.<smiles>Cn1c(/N=C(\N)N2CCCC(NC(=O)OC(C)(C)C)C2)c(Br)c(=O)n(C)c1=O</smiles>

\{1-[N-(5-Bromo-1,3-dimethyl-2,6-dioxo-1,2,3,6-tetrahydro-pyrimidin-4-yl)carbamimidoyl]-piperidin-3-yl \}-carbamic acid tert-butyl ester. (3) To a solution of $141 \mathrm{mg}(0.57 \mathrm{mmol})$ of guanidine 1 in $1 \mathrm{~mL}$ of abs. EtOH was added $223 \mathrm{~mL}$ of $2.54 \mathrm{M}$ KOEt in EtOH. Next, $141 \mathrm{mg}(0.57 \mathrm{mmol})$ of 5-bromo-6-methoxy-1,3-dimethyl-1Hpyrimidine-2,4-dione was added along with $1 \mathrm{~mL}$ of EtOH. The reaction was heated at reflux for $1.5 \mathrm{~h}$, then concentrated in vacuo. The residue was taken up in $5 \mathrm{~mL}$ of ethyl acetate, and the mixture was extracted with water $(1 \times 2 \mathrm{~mL})$ and brine $(1 \times 2 \mathrm{~mL})$, dried over $\mathrm{MgSO}_{4}$, filtered, and concentrated to an oil. This was purified via silica gel chromatography, eluting with ethyl acetate to give $162 \mathrm{mg}(62 \%)$ of the product as a white foam. mp $140{ }^{\circ} \mathrm{C}$ (decomp.). ${ }^{1} \mathrm{H}$ NMR $\left(300 \mathrm{MHz}, \mathrm{DMSO}-d_{6}\right) \delta 6.80(\mathrm{~d}, J=7.5 \mathrm{~Hz}, 1$ H), 6.42 (s, $1 \mathrm{H}), 6.38$ (s, $1 \mathrm{H}), 3.87(\mathrm{~m}, 2 \mathrm{H}), 3.37$ (m, $1 \mathrm{H}), 3.20$ (s, $3 \mathrm{H}), 3.19$ (s, $3 \mathrm{H})$, $2.77(\mathrm{~m}, 2 \mathrm{H}), 1.85(\mathrm{~m}, 1 \mathrm{H}), 1.63(\mathrm{~m}, 1 \mathrm{H}), 1.40(\mathrm{~m}, 2 \mathrm{H}), 1.37(\mathrm{~s}, 9 \mathrm{H})$; MS (ESI) ${ }^{+} \mathrm{m} / z=$ $459(\mathrm{M}+\mathrm{H})^{+}, 461(\mathrm{M}+\mathrm{H})^{+}$. Anal. Calc'd for $\mathrm{C}_{17} \mathrm{H}_{27} \mathrm{BrN}_{6} \mathrm{O}_{4}: \mathrm{C}, 44.45 ; \mathrm{H}, 5.92 ; \mathrm{N}, 18.30$. Found: C, 44.42; H, 5.96; N, 17.93 .<smiles>Cn1c(=O)c2[nH]c(N3CCCC(NC(=O)OC(C)(C)C)C3)nc2n(C)c1=O</smiles>

[1-(1,3-Dimethyl-2,6-dioxo-2,3,6,7-tetrahydro-1H-purin-8-yl)-piperidin-3-yl]carbamic acid tert-butyl ester. (4) A $50 \mathrm{~mL}$ round bottomed flask was charged with 65 $\mathrm{mg}$ of $60 \% \mathrm{NaH}$ in mineral oil. This was washed with hexanes and decanted (3 x $2 \mathrm{~mL})$ to remove the oil. Next, $3 \mathrm{~mL}$ of THF was added, followed by $150 \mathrm{mg}$ of guanidine $\mathbf{1}$, then $3 \mathrm{mg}$ of CuI. The reaction was heated at reflux under $\mathrm{N}_{2}$ for $30 \mathrm{~min}$, then cooled slightly, and treated with $1 \mathrm{~mL}$ of water to quench the remaining $\mathrm{NaH}$. The solvents were removed in vacuo, and the residue was taken up in $3 \mathrm{~mL}$ of water. This was treated with $1.5 \mathrm{~mL}$ of $1 \mathrm{M} \mathrm{HCl}$ to give a very fine precipitate. The suspension was diluted with water to a total volume of $10 \mathrm{~mL}$, then subjected to centrifugation at $800 \mathrm{~g}$ for $1.5 \mathrm{~min}$. The 
water was decanted, and the precipitate was resuspended in water (total volume $=10$ $\mathrm{mL}$ ). This procedure was repeated until the $\mathrm{pH}$ was neutral. The wet precipitate was then suspended in methanol and dried in vacuo to give $96 \mathrm{mg}(77 \%)$ of a white solid. $\mathrm{mp}$ 273-274 ${ }^{\circ} \mathrm{C}$ (with bubbling). ${ }^{1} \mathrm{H}$ NMR (300 MHz, DMSO- $\left.d_{6}\right) \delta 11.68$ (s, $\left.1 \mathrm{H}\right), 6.94$ (d, $J=7.8 \mathrm{~Hz}, 1 \mathrm{H}), 3.90$ (m, $2 \mathrm{H}), 3.36$ (s, $3 \mathrm{H}), 3.29$ (m, $1 \mathrm{H}), 3.19$ (m, $3 \mathrm{H}), 2.91$ (m, $1 \mathrm{H})$, $2.77(\mathrm{~m}, 1 \mathrm{H}), 1.73(\mathrm{~m}, 2 \mathrm{H}), 1.40(\mathrm{~s}, 9 \mathrm{H}), 1.39(\mathrm{~m}, 2 \mathrm{H})$; MS (ESI) ${ }^{+} \mathrm{m} / z=379(\mathrm{M}+\mathrm{H})^{+}$. Anal. Calc'd for $\mathrm{C}_{17} \mathrm{H}_{26} \mathrm{~N}_{6} \mathrm{O}_{4}$ : C, 53.96; H, 6.93; N, 22.21. Found: C, 54.08; H, 6.88; N, 21.95.<smiles>CC(C)(C)OC(=O)NC1CCCN(/C(N)=N/c2cnn(Cc3ccc(Cl)cc3)c(=O)c2Br)C1</smiles>

(1-\{ $N$-[5-Bromo-1-(4-chloro-benzyl)-6-oxo-1,6-dihydro-pyridazin-4-yl]carbamimidoyl\}-piperidin-3-yl)-carbamic acid tert-butyl ester. A mixture of $102 \mathrm{mg}$ (0.269 mmol) of 4,5-dibromo-2-(4-chloro-benzyl)-2H-pyridazin-3-one, ${ }^{2} 75 \mathrm{mg}(0.269$ $\mathrm{mmol}$ ) of (1-carbamimidoyl-piperidin-3-yl)-carbamic acid tert-butyl ester hydrochloride, and $186 \mathrm{mg}(1.35 \mathrm{mmol})$ of $\mathrm{K}_{2} \mathrm{CO}_{3}$ was stirred in $75 \mu \mathrm{L}$ of $\mathrm{H}_{2} \mathrm{O}$ and $1.5 \mathrm{~mL}$ of DMF at $65{ }^{\circ} \mathrm{C}$ for $18 \mathrm{~h}$. The reaction mixture was cooled to $23{ }^{\circ} \mathrm{C}$, quenched with $2 \mathrm{~mL}$ of water, and extracted with $4 \mathrm{~mL}$ of methylene chloride $(3 \mathrm{x})$. The methylene chloride layer was dried over $\mathrm{Na}_{2} \mathrm{SO}_{4}$, filtered and concentrated in vacuo. The residue was purified via silica gel chromatography eluting with 97.5: 2.5 ethyl acetate: methanol to afford $97 \mathrm{mg}(67 \%)$ of the product as a light yellow solid. mp 203-204 ${ }^{\circ} \mathrm{C}$. ${ }^{1} \mathrm{H}$ NMR $\left(500 \mathrm{MHz}, \mathrm{DMSO}-d_{6}\right)$ mixture of structural isomers $\delta 7.80(\mathrm{~s}, 0.2 \mathrm{H}), 7.46(\mathrm{~s}, 0.8 \mathrm{H}), 7.38(\mathrm{~m}, 2 \mathrm{H}), 7.32(\mathrm{~d}, \mathrm{~J}=8$ $\mathrm{Hz}, 2 \mathrm{H}), 6.88(\mathrm{~d}, \mathrm{~J}=8 \mathrm{~Hz}, 0.8 \mathrm{H}), 6.85(\mathrm{~d}, \mathrm{~J}=8 \mathrm{~Hz}, 0.2 \mathrm{H}), 6.50(\mathrm{~s}, 1.6 \mathrm{H}), 6.25(\mathrm{~s}, 0.4 \mathrm{H})$, $5.16(\mathrm{~m}, 2 \mathrm{H}), 3.74(\mathrm{~m}, 2 \mathrm{H}), 3.38(\mathrm{bs}, 1 \mathrm{H}), 2.88(\mathrm{~m}, 2 \mathrm{H}), 1.78(\mathrm{~m}, 1 \mathrm{H}), 1.66(\mathrm{~m}, 1 \mathrm{H}), 1.36$ $(\mathrm{m}, 11 \mathrm{H}) ; \mathrm{MS}(\mathrm{DCI})^{+} \mathrm{m} / \mathrm{z}=539(\mathrm{M}+\mathrm{H})^{+}$. Anal. Calc'd for $\mathrm{C}_{22} \mathrm{H}_{28} \mathrm{BrClN}_{6} \mathrm{O}_{3}: \mathrm{C}, 48.95 ; \mathrm{H}$, 5.23; N, 15.57. Found: C, 49.27; H, 5.05; N, 15.54 .

\section{BocHN}

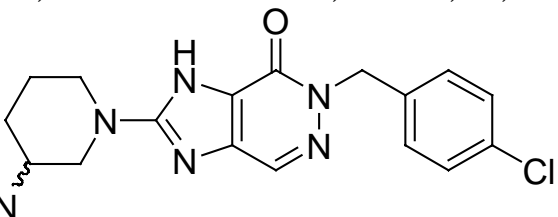

\section{\{1-[6-(4-Chloro-benzyl)-7-oxo-6,7-dihydro-1H-imidazo[4,5-d]pyridazin-2-yl]-}

piperidin-3-yl $\}$-carbamic acid tert-butyl ester. To a solution of $50 \mathrm{mg}(0.093 \mathrm{mmol})$ of (1- $\{N$-[5-bromo-1-(4-chloro-benzyl)-6-oxo-1,6-dihydro-pyridazin-4-yl]-carbamimidoyl $\}$ piperidin-3-yl)-carbamic acid tert-butyl ester in $2.2 \mathrm{~mL}$ of THF at $23{ }^{\circ} \mathrm{C}$ was sequentially added $8.5 \mathrm{mg}(0.045 \mathrm{mmol})$ of $\mathrm{CuI}$ and $5.6 \mathrm{mg}(0.139 \mathrm{mmol})$ of $60 \% \mathrm{NaH}$ in mineral oil. The reaction mixture was heated at reflux for $1 \mathrm{~h}$. The reaction mixture was diluted with $4 \mathrm{~mL}$ of methylene chloride, then $1 \mathrm{~mL}$ of saturated $\mathrm{NH}_{4} \mathrm{Cl}_{(a q .)}$ was added, followed by 2 $\mathrm{mL}$ of saturated $\mathrm{NaHCO}_{3(a q .)}$. The layers were separated and the aqueous solution extracted with $4 \mathrm{~mL}$ methylene chloride $(3 \mathrm{x})$. The combined organic layers were dried over $\mathrm{Na}_{2} \mathrm{SO}_{4}$ and concentrated in vacuo. The residue was precipitated from ethyl acetate/hexanes to obtain a light tan solid (35 mg, 81\% yield). ${ }^{1} \mathrm{H}$ NMR (500 MHz, DMSO- $\left.d_{6}\right) \delta 12.48$ (bs, 1H), $8.13(\mathrm{bs}, 1 \mathrm{H}), 7.37$ (bs, 2H), 7.27 (bs, 2H), 6.93 (bs, 1H), $5.31(\mathrm{~s}, 2 \mathrm{H}), 4.09$ (bs, 1H), 3.94 (bs, 1H), 3.38 (bs, 1H), 2.95 (bs, 1H), 2.80 (bs, 1H), 1.77 $(\mathrm{m}, 2 \mathrm{H}), 1.32(\mathrm{~m}, 11 \mathrm{H}) ; \mathrm{MS}(\mathrm{DCI})^{+} \mathrm{m} / \mathrm{z}=459(\mathrm{M}+\mathrm{H})^{+}$; HRMS Calc' d for $\mathrm{C}_{22} \mathrm{H}_{28} \mathrm{ClN}_{6} \mathrm{O}_{3}$ 
$(\mathrm{M}+\mathrm{H})^{+}: m / z=459.1906$. Observed $m / z=459.1913$. Anal. Calc'd for $\mathrm{C}_{22} \mathrm{H}_{27} \mathrm{ClN}_{6} \mathrm{O}_{3} \cdot 0.55$ EtOAc: C,57.28; H,6.24; N, 16.53. Found: C, 57.20; H, 6.30; N, 16.53 .<smiles>O=C1C(Br)=C(N=C(NCc2ccccc2)N2CCOCC2)C(=O)c2ccccc21</smiles>

N-Benzyl-N'-(3-bromo-1,4-dioxo-1,4-dihydro-naphthalen-2-yl)-morpholine-4carboxamidine. 2,3-Dibromo-1,4-naphthoquinone $(0.100 \mathrm{~g}, 0.48 \mathrm{mmol}), \mathrm{N}$-benzylmorpholine-4-carboxamidine hydriodide ${ }^{3}(0.165 \mathrm{~g}, 0.48 \mathrm{mmol})$, and $\mathrm{K}_{2} \mathrm{CO}_{3}(0.131 \mathrm{~g}$, $0.95 \mathrm{mmol}$ ) were stirred in DMF $(4 \mathrm{~mL})$ at $23{ }^{\circ} \mathrm{C}$ for $18 \mathrm{~h}$. The reaction mixture was quenched with $10 \mathrm{~mL}$ of water and extracted with $10 \mathrm{~mL}$ of methylene chloride $(3 \mathrm{x})$. The methylene chloride layer was dried over $\mathrm{Na}_{2} \mathrm{SO}_{4}$, filtered, and concentrated in vacuo. The product was purified via silica gel chromatography eluting with a rapid gradient of 100:0 to 20:80 hexanes: ethyl acetate to afford $158 \mathrm{mg}(72 \%)$ of a deep purple solid. mp 174$176{ }^{\circ} \mathrm{C} .{ }^{1} \mathrm{H}$ NMR $\left(400 \mathrm{MHz}, \mathrm{DMSO} d_{6}\right) \delta \mathrm{d} 8.26(\mathrm{t}, \mathrm{J}=6 \mathrm{~Hz}, 1 \mathrm{H}), 7.91(\mathrm{dd}, \mathrm{J}=1,8 \mathrm{~Hz}$, 1H), $7.72(\mathrm{~m}, 2 \mathrm{H}), 7.59$ (ddd, J = 1, 8, $8 \mathrm{~Hz}, 1 \mathrm{H}), 7.19(\mathrm{~d}, \mathrm{~J}=7 \mathrm{~Hz}, 2 \mathrm{H}), 7.12$ (dd, J = 7, 7Hz, 2H), 7.01 (dd, J, 7, $7 \mathrm{~Hz}, 1 \mathrm{H}), 4.19$ (bs, 2H), 3.62 (t, J = $5 \mathrm{~Hz}, 4 \mathrm{H}), 3.34$ (t, J = $5 \mathrm{~Hz}$, $4 \mathrm{H})$; MS $(\mathrm{DCI})^{+} \mathrm{m} / z=454(\mathrm{M}+\mathrm{H})^{+}$. Anal. Calc'd for $\mathrm{C}_{22} \mathrm{H}_{20} \mathrm{BrN}_{3} \mathrm{O}_{3} \mathrm{C}, 58.16 ; \mathrm{H}, 4.44$; N, 9.25. Found: C, 58.17; H, 4.34; N, 9.14.<smiles>O=C1c2ccccc2C(=O)c2c1nc(N1CCOCC1)n2Cc1ccccc1</smiles>

1-Benzyl-2-morpholin-4-yl-1H-naphtho[2,3-d]imidazole-4,9-dione.To a stirred, $23{ }^{\circ} \mathrm{C}$ solution of $71 \mathrm{mg}(0.156 \mathrm{mmol}) \mathrm{N}$-benzyl- $N$ '-(3-bromo-1,4-dioxo-1,4-dihydronaphthalen-2-yl)-morpholine-4-carboxamidine in $4 \mathrm{~mL}$ of THF was sequentially added $\mathrm{CuI}(6 \mathrm{mg}, 0.031 \mathrm{mmol})$ and $60 \% \mathrm{NaH}$ in mineral oil $(9.4 \mathrm{mg}, 0.234 \mathrm{mmol})$. The reaction mixture was heated at reflux for 1 hour. The cooled reaction mixture was diluted with $4 \mathrm{~mL}$ of methylene chloride before quenching sequentially with $1 \mathrm{~mL}$ of sat. $\mathrm{NH}_{4} \mathrm{Cl}$ solution and $2 \mathrm{~mL}$ of sat. $\mathrm{NaHCO}_{3}$ solution. The layers were separated and the aqueous solution extracted with $4 \mathrm{~mL}$ methylene chloride $(3 \mathrm{x})$. The combined organic phase was dried over $\mathrm{Na}_{2} \mathrm{SO}_{4}$, filtered, and concentrated in vacuo. The residue was purified via silica gel chromatography eluting with a rapid gradient of 100:0 to 20:80 hexanes: ethyl acetate to obtain a rust orange solid $(0.049 \mathrm{~g}, 84 \%$ yield $) . \mathrm{mp} 191-192{ }^{\circ} \mathrm{C}$. ${ }^{1} \mathrm{HNMR}(400$ MHz, DMSO- $\left.d_{6}\right) \delta 8.04(\mathrm{~m}, 1 \mathrm{H}), 7.96(\mathrm{~m}, 1 \mathrm{H}), 7.79(\mathrm{~m}, 2 \mathrm{H}), 7.33(\mathrm{dd}, \mathrm{J}=7,7 \mathrm{~Hz}, 2 \mathrm{H})$, $7.26(\mathrm{dd}, \mathrm{J}=7,7 \mathrm{~Hz}, 1 \mathrm{H}), 7.19(\mathrm{~d}, \mathrm{~J}=7 \mathrm{~Hz}, 1 \mathrm{H}), 5.56(\mathrm{~s}, 2 \mathrm{H}), 3.65(\mathrm{t}, \mathrm{J}=5 \mathrm{~Hz}, 4 \mathrm{H})$, $3.12(\mathrm{t}, \mathrm{J}=5 \mathrm{~Hz}, 4 \mathrm{H})$; MS $(\mathrm{DCI})^{+} \mathrm{m} / \mathrm{z}=374(\mathrm{M}+\mathrm{H})^{+}$. Anal. Calc'd for $\mathrm{C}_{22} \mathrm{H}_{19} \mathrm{~N}_{3} \mathrm{O}_{3}: \mathrm{C}_{\text {, }}$ 70.76; H, 5.13; N, 11.25. Found: C, 70.36; H, 5.01; N, 11.07. 


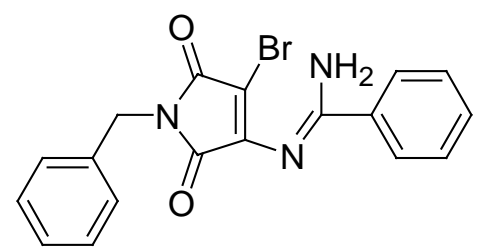

$N$-(1-Benzyl-4-bromo-2,5-dioxo-2,5-dihydro-1H-pyrrol-3-yl)-benzamidine. $N$ Benzyl-2,3-dibromo-maleimide $(0.25 \mathrm{~g}, 0.73 \mathrm{mmol})$, bezamidine hydrochloride $(0.114 \mathrm{~g}$, $0.73 \mathrm{mmol})$ and $\mathrm{K}_{2} \mathrm{CO}_{3}(0.502 \mathrm{~g}, 3.64 \mathrm{mmol})$ were stirred in DMF at ambient temperature for 3 hours. The reaction was quenched with $20 \mathrm{~mL}$ of sat. $\mathrm{NH}_{4} \mathrm{Cl}$ and extracted with $50 \mathrm{~mL}$ of EtOAc. The organic layer was washed with $20 \mathrm{~mL}$ of brine, dried over $\mathrm{MgSO}_{4}$, filtered and concentrated in vacuo. The product was purified via silica gel chromatography, eluting with 60: 40 hexanes: EtOAc, to provide $221 \mathrm{mg}(79 \%)$ of a yellow solid. mp 168-170 ${ }^{\circ} \mathrm{C} .{ }^{1} \mathrm{H}$ NMR $\left(300 \mathrm{MHz}, \mathrm{CDCl}_{3}\right) \delta 7.69(\mathrm{~m}, 2 \mathrm{H}), 7.58(\mathrm{~m}, 2 \mathrm{H})$, $7.45(\mathrm{~m}, 3 \mathrm{H}), 7.26(\mathrm{~m}, 3 \mathrm{H}), 7.21(\mathrm{~b}, 2 \mathrm{H}), 4.62(\mathrm{~s}, 2 \mathrm{H}) . \mathrm{MS}(\mathrm{ESI})^{+} \mathrm{m} / z=384(\mathrm{M}+\mathrm{H})^{+}$. Anal. Calc'd for $\mathrm{C}_{18} \mathrm{H}_{14} \mathrm{BrN}_{3} \mathrm{O}_{2}$ : C, 56.27; H, 3.67; N, 10.94. Found: C, 56.49; H, 3.60; N, 10.68 .<smiles>O=C1c2nc(-c3ccccc3)[nH]c2C(=O)N1Cc1ccccc1</smiles>

5-Benzyl-2-phenyl-1H-pyrrolo[3,4-d]imidazole-4,6-dione. To $210 \mathrm{mg}(0.55 \mathrm{mmol})$ of $N$-(1-Benzyl-4-bromo-2,5-dioxo-2,5-dihydro-1H-pyrrol-3-yl)-benzamidine in $3 \mathrm{~mL}$ of THF was added $\mathrm{CuI}(10 \mathrm{mg}, 0.052 \mathrm{mmol})$. To the mixture was added $35.7 \mathrm{mg}(0.89$ mmol) of $60 \% \mathrm{NaH}$ in mineral oil, then the reaction was stirred at $25{ }^{\circ} \mathrm{C}$ for 1 hour. The reaction was quenched with $20 \mathrm{~mL}$ of sat. $\mathrm{NH}_{4} \mathrm{Cl}$ and extracted with $50 \mathrm{~mL}$ of EtOAc. The organic phase was washed with $20 \mathrm{~mL}$ of brine, dried over $\mathrm{MgSO}_{4}$ and concentrated in vacuo. The product was recrystallized from EtOAc: hexanes (1: 4) to obtain $112 \mathrm{mg}$ (94\%) of an orange colored solid. mp 291-293 ${ }^{\circ} \mathrm{C} .{ }^{1} \mathrm{HNMR}\left(300 \mathrm{MHz}, \mathrm{CDCl}_{3}\right) \delta 14.21$ (s, $1 \mathrm{H}), 8.06(\mathrm{~m}, 2 \mathrm{H}), 7.53(\mathrm{~m}, 3 \mathrm{H}), 7.32(\mathrm{~m}, 5 \mathrm{H}), 4.67(\mathrm{~s}, 2 \mathrm{H})$. MS (APCI) ${ }^{+} \mathrm{m} / z=304.5$ $(\mathrm{M}+\mathrm{H})^{+}$. Anal. Calc'd for $\mathrm{C}_{18} \mathrm{H}_{13} \mathrm{~N}_{3} \mathrm{O}_{2}$ : C, 71.28; H, 4.32; N, 13.85. Found: C, 70.95; H, $4.20 ; \mathrm{N}, 13.70$.<smiles>CN1C(=O)C(Br)=C(NC(=N)N2CCCC(NC(=O)OC(C)(C)C)C2)C1=O</smiles>

\{1-[N-(4-Bromo-1-methyl-2,5-dioxo-2,5-dihydro-1H-pyrrol-3-yl)-carbamimidoyl]piperidin-3-yl -carbamic acid tert-butyl ester. $N$-methyl-2,3-dibromo-maleimide $(0.25$ g, $0.939 \mathrm{mmol}$ ), 1-(cabamimidoyl-piperidin-3-yl)carbamic acid tert-butyl ester.HCl $(0.261 \mathrm{~g}, 0.939 \mathrm{mmol})$ and $\mathrm{K}_{2} \mathrm{CO}_{3}(0.647 \mathrm{~g}, 4.69 \mathrm{mmol})$ were stirred in $3 \mathrm{~mL}$ of DMF at ambient temperature for $3 \mathrm{~h}$. The reaction was quenched with $20 \mathrm{~mL}$ of saturated $\mathrm{NH}_{4} \mathrm{Cl}_{(a q .)}$ and extracted with $50 \mathrm{~mL}$ of EtOAc. The organic layer was washed with 20 
$\mathrm{mL}$ of brine, dried with $\mathrm{MgSO}_{4}$, filtered and evaporated to dryness. The product was purified via silica gel chromatography, eluting with 75:25 EtOAc: hexanes to provide $330 \mathrm{mg}(70 \%)$ of a yellow solid. mp $127-129^{\circ} \mathrm{C} .{ }^{1} \mathrm{H} \mathrm{NMR}\left(300 \mathrm{MHz}, \mathrm{CDCl}_{3}\right) \delta 8.02(\mathrm{~s}$, 1H), 4.77 (br, 1H) 3.63 (br, 2H), 2.88 (s, 3H), 1.87 (m, 2H), 1.65 (m, 4H), 1.44 (s, 9H), $1.36(\mathrm{~m}, 2 \mathrm{H}) . \mathrm{MS}(\mathrm{CI})^{+} \mathrm{m} / z=431(\mathrm{M}+\mathrm{H})^{+}$. Anal. Calc'd for $\mathrm{C}_{16} \mathrm{H}_{24} \mathrm{BrN}_{5} \mathrm{O}_{4}: \mathrm{C}, 44.65 ; \mathrm{H}$, 5.56; N, 16.27. Found: C, 44.85; H, 5.47; N, 16.16.<smiles>CN1C(=O)c2nc(N3CCCC(NC(=O)OCc4ccccc4)C3)[nH]c2C1=O</smiles>

[1-(5-Methyl-4,6-dioxo-1,4,5,6-tetrahydro-pyrrolo[3,4-d]imidazol-2-yl)-piperidin-3yl]-carbamic acid tert-butyl ester. To a solution of $256 \mathrm{mg}(0.595 \mathrm{mmol})$ of 1 -[ $\mathrm{N}-(4-$ bromo-1-methyl-2,5-dioxo-2,5-dihydro-1H-pyrrol-3-yl)-carbamimidoyl]-piperidin-3-yl \}carbamic acid tert-butyl ester in $3 \mathrm{~mL}$ of THF was added $10 \mathrm{mg}(0.052 \mathrm{mmol})$ of CuI $(10 \mathrm{mg}, 0.052 \mathrm{mmol})$, then $35.7 \mathrm{mg}(0.89 \mathrm{mmol})$ of $60 \% \mathrm{NaH}$ in mineral oil. The reaction was stirred at $25{ }^{\circ} \mathrm{C}$ for $1 \mathrm{~h}$, then $20 \mathrm{~mL}$ of sat. $\mathrm{NH}_{4} \mathrm{Cl}_{(a q)}$. was added, and the mixture was extracted with $50 \mathrm{~mL}$ of EtOAc. The organic phase was washed with $20 \mathrm{~mL}$ of brine, dried over $\mathrm{MgSO}_{4}$ and concentrated in vacuo. The product was recrystallized from EtOAc/hexanes (1:4) to obtain $114 \mathrm{mg}(55 \%)$ of an orange solid. mp 226-228 ${ }^{\circ} \mathrm{C} .{ }^{1} \mathrm{HNMR}\left(300 \mathrm{MHz}, \mathrm{DMSO}-d_{6}\right) \delta 6.93(\mathrm{~d}, 1 \mathrm{H}), 3.92(\mathrm{~b}, 1 \mathrm{H}), 3.77(\mathrm{~m}, 1 \mathrm{H}), 2.84(\mathrm{~s}$, $3 \mathrm{H}), 1.87$ (m, 2H), $1.65(\mathrm{~m}, 4 \mathrm{H}), 1.40(\mathrm{~s}, 9 \mathrm{H}), 1.37(\mathrm{~m}, 2 \mathrm{H}) . \mathrm{MS}(\mathrm{CI})^{+} \mathrm{m} / z=350$ $(\mathrm{M}+\mathrm{H})^{+}$; HRMS Calc'd for $\mathrm{C}_{16} \mathrm{H}_{24} \mathrm{~N}_{5} \mathrm{O}_{4}(\mathrm{M}+\mathrm{H})^{+}: \mathrm{m} / z=350.1823$. Observed $\mathrm{m} / z=$ 350.1822. Anal. Calc'd for $\mathrm{C}_{16} \mathrm{H}_{23} \mathrm{~N}_{5} \mathrm{O}_{4} \cdot 0.11$ EtOAc: C, 54.99; H, 6.70; N, 19.50. Found: C, 55.00; H, 6.67; N, 19.48.<smiles>CC(C)(C)OC(=O)NC1CCCN(/C(N)=N/c2ncnc(Cl)c2Br)C1</smiles>

\{1-[N-(5-Bromo-6-chloro-pyrimidin-4-yl)-carbamimidoyl]-piperidin-3-yl\}-carbamic acid tert-butyl ester. To $409 \mathrm{mg}(1.80 \mathrm{mmol})$ of 5-bromo-4,6-dichloropyrimidine, ${ }^{4} 500$ $\mathrm{mg}(1.80 \mathrm{mmol})$ of guanidine 1 , and $500 \mathrm{mg}(3.62 \mathrm{mmol})$ of $\mathrm{K}_{2} \mathrm{CO}_{3}$ was added $5 \mathrm{~mL}$ of DMSO. The mixture was stirred at ambient temperature for $2.25 \mathrm{~h}$. The reaction was diluted with $20 \mathrm{~mL}$ of water, then extracted with diethyl ether $(3 \times 10 \mathrm{~mL})$. The combined ether layers were back extracted with water $(1 \times 10 \mathrm{~mL})$, and brine $(1 \times 10$ $\mathrm{mL}$ ), dried over $\mathrm{MgSO}_{4}$, filtered, and concentrated with $5 \mathrm{~mL}$ of silica gel. The product was purified via silica gel chromatography, eluting with 1: 1 ethyl acetate: hexanes to give $227 \mathrm{mg}$ (29\%) of a white solid. The product contained some of the inseparable 5chloropyrimidine analog. ${ }^{1} \mathrm{H}$ NMR $\left(300 \mathrm{MHz}, \mathrm{DMSO}-d_{6}\right) \delta 8.47(\mathrm{~s}, 2 \mathrm{H}), 8.26(\mathrm{~m}, 1 \mathrm{H})$, $6.92(\mathrm{~d}, J=7.5 \mathrm{~Hz}, 1 \mathrm{H}), 4.05(\mathrm{~m}, 2 \mathrm{H}), 3.35(\mathrm{~m}, 1 \mathrm{H}), 2.96(\mathrm{~m}, 2 \mathrm{H}), 1.83(\mathrm{~m}, 1 \mathrm{H}), 1.75$ $(\mathrm{m}, 1 \mathrm{H}), 1.38(\mathrm{~s}, 9 \mathrm{H}), 1.41(\mathrm{~m}, 2 \mathrm{H}) ; \mathrm{MS}(\mathrm{ESI})^{+} \mathrm{m} / \mathrm{z}=435(\mathrm{M}+\mathrm{H})^{+}$. 
<smiles>CC(C)(C)OC(=O)NC1CCCN(c2nc3ncnc(Cl)c3[nH]2)C1</smiles>

[1-(6-Chloro-7H-purin-8-yl)-piperidin-3-yl]-carbamic acid tert-butyl ester. To a mixture of $222 \mathrm{mg}(0.512 \mathrm{mmol})$ of $\{1-[N$-(5-bromo-6-chloro-pyrimidin-4-yl)carbamimidoyl]-piperidin-3-yl -carbamic acid tert-butyl ester, $30 \mathrm{mg}(0.75 \mathrm{mmol})$ of $60 \% \mathrm{NaH}$ in mineral oil, and $5 \mathrm{mg}(0.026 \mathrm{mmol})$ of $\mathrm{CuI}$ was added $3 \mathrm{~mL}$ of THF. The mixture was heated at reflux for $30 \mathrm{~min}$, then concentrated in vacuo. The residue was carefully quenched with $10 \mathrm{~mL}$ of $0.5 \mathrm{M} \mathrm{HCl}$, then treated with $6 \mathrm{~mL}$ of saturated $\mathrm{NaHCO}_{3(a q .)}$. The suspension was extracted with ethyl acetate $(3 \times 5 \mathrm{~mL})$, then the combined ethyl acetate layers were back extracted with brine $(1 \times 5 \mathrm{~mL})$, dried over $\mathrm{MgSO}_{4}$, filtered, and concentrated to a foam. The product was purified via silica gel chromatography, eluting with 95:5 ethyl acetate: methanol to give $98 \mathrm{mg}$ (73\%) of the purine. mp 200-202 ${ }^{\circ} \mathrm{C}$ (with bubbling). ${ }^{1} \mathrm{H}$ NMR (300 MHz, DMSO- $\left.d_{6}\right) \delta 12.73$ (s, 0.5 $\mathrm{H}), 12.02(\mathrm{~s}, 0.5 \mathrm{H}), 8.32(\mathrm{~s}, 1 \mathrm{H}), 7.00(\mathrm{~d}, J=7.5 \mathrm{~Hz}, 1 \mathrm{H}), 4.02(\mathrm{~m}, 2 \mathrm{H}), 3.44(\mathrm{~m}, 1 \mathrm{H})$, $3.12(\mathrm{~m}, 2 \mathrm{H}), 1.81(\mathrm{~m}, 2 \mathrm{H}), 1.40(\mathrm{~s}, 9 \mathrm{H}), 1.47(\mathrm{~m}, 2 \mathrm{H}) ; \mathrm{MS}(\mathrm{ESI})^{+} \mathrm{m} / z=353(\mathrm{M}+\mathrm{H})^{+}$. Anal. Calc'd for $\mathrm{C}_{15} \mathrm{H}_{21} \mathrm{ClN}_{6} \mathrm{O}_{2}$ : C, 51.06; H, 6.00; N, 23.82. Found: C, 51.04; H, 5.95; $\mathrm{N}, 23.43$. In addition, $58 \mathrm{mg}$ of $\{1-[N-(5,6-D i c h l o r o-p y r i m i d i n-4-y l)-c a r b a m i m i d o y l]-$ piperidin-3-yl\}-carbamic acid tert-butyl ester was isolated. Further heating did not result in any conversion of the chloride to the purine. ${ }^{1} \mathrm{H}$ NMR $\left(300 \mathrm{MHz}, \mathrm{DMSO}-d_{6}\right) \delta 8.47$ (s, $2 \mathrm{H}), 8.25$ (s, $1 \mathrm{H}), 6.92$ (d, J=7.5 Hz, $1 \mathrm{H}), 4.15$ (m, $2 \mathrm{H}), 3.41(\mathrm{~m}, 1 \mathrm{H}), 2.99$ (m, $2 \mathrm{H})$, $1.85(\mathrm{~m}, 1 \mathrm{H}), 1.73(\mathrm{~m}, 1 \mathrm{H}), 1.38(\mathrm{~m}, 9 \mathrm{H}), 1.42(\mathrm{~m}, 2 \mathrm{H}) ; \mathrm{MS}(\mathrm{ESI})^{+} \mathrm{m} / z=389(\mathrm{M}+\mathrm{H})^{+}$.<smiles>Cn1c(NC(=N)c2ccccc2)c(Br)c(=O)n(C)c1=O</smiles>

N-(5-Bromo-1,3-dimethyl-2,6-dioxo-1,2,3,6-tetrahydro-pyrimidin-4-yl)benzamidine. To a solution of $100 \mathrm{mg}(0.394 \mathrm{mmol})$ of 5-bromo-6-chlorouracil ${ }^{5}$ and 63 $\mathrm{mg}(0.394 \mathrm{mmol})$ of benzamidine in $2 \mathrm{~mL}$ of $\mathrm{DMF}$ was added $550 \mu \mathrm{L}$ of $2 \mathrm{M} \mathrm{K}_{2} \mathrm{CO}_{3 \text { (aq.) }}$. The reaction was stirred at $80{ }^{\circ} \mathrm{C}$ for $1 \mathrm{~h}$, then diluted with $20 \mathrm{~mL}$ of ethyl acetate and 5 $\mathrm{mL}$ hexanes. The suspension was extracted with water $(2 \times 10 \mathrm{~mL})$, then the combined aqueous layers were back extracted with ethyl acetate $(1 \times 10 \mathrm{~mL})$. The combined organic layers were extracted with brine (1 x $10 \mathrm{~mL})$, dried over $\mathrm{MgSO}_{4}$, filtered, and concentrated in vacuo to an oil. The product was purified via silica gel chromatography, eluting with 3: 1 ethyl acetate: hexanes to give $84 \mathrm{mg}(63 \%)$ of a white solid. $\mathrm{mp} 231-232$ ${ }^{\circ} \mathrm{C} .{ }^{1} \mathrm{H}$ NMR $\left(300 \mathrm{MHz}, \mathrm{DMSO}-d_{6}\right) \delta 7.94(\mathrm{~m}, 2 \mathrm{H}), 7.58(\mathrm{~m}, 1 \mathrm{H}), 7.51(\mathrm{~m}, 2 \mathrm{H}), 3.24$ (s, $3 \mathrm{H}), 3.22(\mathrm{~s}, 3 \mathrm{H})$; MS $(\mathrm{ESI})^{+} \mathrm{m} / z=337(\mathrm{M}+\mathrm{H})^{+}, 339(\mathrm{M}+\mathrm{H})^{+}$. Anal. Calc'd for $\mathrm{C}_{13} \mathrm{H}_{13} \mathrm{BrN}_{4} \mathrm{O}_{2}$ : C, 46.31; H, 3.89; N, 16.62. Found: C, 46.19; H, 3.93; N, 16.32. 
<smiles>Cn1c(=O)c2nc(-c3ccccc3)[nH]c2n(C)c1=O</smiles>

1,3-Dimethyl-8-phenyl-3,7-dihydro-purine-2,6-dione. To a solution of $82 \mathrm{mg}(0.24$ mmol) of $N$-(5-bromo-1,3-dimethyl-2,6-dioxo-1,2,3,6-tetrahydro-pyrimidin-4-yl)benzamidine in $1 \mathrm{~mL}$ of THF was added $30 \mathrm{mg}(0.75 \mathrm{mmol})$ of $60 \% \mathrm{NaH}$ in mineral oil, then $2 \mathrm{mg}(0.010 \mathrm{mmol})$ of CuI. The reaction was heated at reflux for $5 \mathrm{~min}$, then it was cooled and $1 \mathrm{~mL}$ of water was added. The solvents were removed in vacuo, and the residue was taken up in $5 \mathrm{~mL}$ of water. The aqueous solution was extracted with diethyl ether $(3 \times 1 \mathrm{~mL})$, then filtered through a plug of diatomaceous earth to remove a small amount of insoluble material. The filtered solution was made acidic by addition of $1 \mathrm{~mL}$ of $1 \mathrm{M} \mathrm{HCl}$ to give a flocculent white precipitate. This suspension was briefly subjected to centrifugation to facilitate precipitation of the product, then most of the aqueous layer was drained. The precipitate was again suspended in $5 \mathrm{~mL}$ of water, and this process was repeated two more times. The wet precipitate was suspended in methanol and concentrated to dryness to give $51 \mathrm{mg}(82 \%)$ of 1,3-dimethyl-7-phenyl xanthine as a white solid. Any remaining mineral oil was removed by trituration with diethyl ether if necessary. $\mathrm{mp}>310^{\circ} \mathrm{C}$. Spectral data were in agreement with those previously reported. ${ }^{6}{ }^{1} \mathrm{H}$ NMR $\left(300 \mathrm{MHz}, \mathrm{DMSO}-d_{6}\right) \delta 13.86(\mathrm{~s}, 1 \mathrm{H}), 8.15(\mathrm{~m}, 2 \mathrm{H}), 7.52(\mathrm{~m}, 3 \mathrm{H})$, $3.52(\mathrm{~s}, 3 \mathrm{H}), 3.32\left(\mathrm{H}_{2} \mathrm{O}\right), 3.28(\mathrm{~s}, 3 \mathrm{H})$; $\mathrm{MS}(\mathrm{ESI})^{+} \mathrm{m} / \mathrm{z}=257(\mathrm{M}+\mathrm{H})^{+}$.<smiles>Cn1c(/N=C(\N)c2ccc(Br)cc2)c(Br)c(=O)n(C)c1=O</smiles>

4-Bromo- $N$-(5-bromo-1,3-dimethyl-2,6-dioxo-1,2,3,6-tetrahydro-pyrimidin-4-yl)benzamidine. To $253 \mathrm{mg}(1.00 \mathrm{mmol})$ of 5-bromo-6-chlorouracil and $250 \mathrm{mg}(1.06$ mmol) of 4-bromobenzamidine hydrochloride was added $7 \mathrm{~mL}$ of DMF, then $2 \mathrm{~mL}$ of $2 \mathrm{M} \mathrm{K}_{2} \mathrm{CO}_{3 \text { (aq.) }}$. The reaction was stirred at $90{ }^{\circ} \mathrm{C}$ for $1 \mathrm{~h}$, then concentrated in vacuo. The residue was taken up in $10 \mathrm{~mL}$ of ethyl acetate and extracted with $\mathrm{H}_{2} \mathrm{O}(2 \times 5 \mathrm{~mL})$, adding saturated $\mathrm{NaHCO}_{3(\text { aq. }}$ as necessary to break emulsions, then brine $(1 \mathrm{x} 5 \mathrm{~mL})$, dried over $\mathrm{MgSO}_{4}$, filtered, and concentrated in vacuo to a foam. This was purified via silica gel chromatography, eluting with 75: 25 ethyl acetate: hexanes to give $203 \mathrm{mg}$ (49\%) of a white solid. mp 250-251 ${ }^{\circ} \mathrm{C} .{ }^{1} \mathrm{H}$ NMR (300 MHz, DMSO- $\left.d_{6}\right)$ mixture of rotamers $\delta 8.03(\mathrm{bs}, 1 \mathrm{H}), 7.88(\mathrm{~m}, 2 \mathrm{H}), 7.81$ (minor rotamer) $(\mathrm{m}, 2 \mathrm{H}), 7.73(\mathrm{~m}, 2 \mathrm{H})$, 7.67 (minor rotamer) $(\mathrm{m}, 2 \mathrm{H}), 7.45(\mathrm{bs}, 1 \mathrm{H}), 3.24(\mathrm{~s}, 3 \mathrm{H}), 3.21(\mathrm{~s}, 3 \mathrm{H}) ; \mathrm{MS}(\mathrm{ESI})^{+} \mathrm{m} / \mathrm{z}$ $=417(\mathrm{M}+\mathrm{H})^{+}$. Anal. Calc'd for $\mathrm{C}_{13} \mathrm{H}_{12} \mathrm{Br}_{2} \mathrm{~N}_{4} \mathrm{O}_{2}$ : C, 37.53; H, 2.91; N, 13.47. Found: $\mathrm{C}$, 37.77; H, 2.95; N, 13.25.<smiles>Cn1c(=O)c2[nH]c(-c3ccc(Br)cc3)nc2n(C)c1=O</smiles> 
8-(4-Bromo-phenyl)-1,3-dimethyl-3,7-dihydro-purine-2,6-dione. To $165 \mathrm{mg}(0.396$ $\mathrm{mmol}$ ) of 4-bromo- $N$-(5-bromo-1,3-dimethyl-2,6-dioxo-1,2,3,6-tetrahydro-pyrimidin-4yl)-benzamidine in $4 \mathrm{~mL}$ of THF was added $80 \mathrm{mg}$ of $60 \% \mathrm{NaH}$ in mineral oil, then $4 \mathrm{mg}$ (0.02 mmol) of CuI. The reaction was heated at reflux for $30 \mathrm{~min}$, then $2 \mathrm{~mL}$ of water was added and the solvents were removed in vacuo. The residue was taken up in $15 \mathrm{~mL}$ of $\mathrm{H}_{2} \mathrm{O}$, and extracted with diethyl ether $(1 \times 5 \mathrm{~mL})$, and hexanes $(2 \times 5 \mathrm{~mL})$. The aqueous layer was then acidified with $2 \mathrm{~mL}$ of $1 \mathrm{M} \mathrm{HCl}$ to give a very fine precipitate. This suspension was diluted to $10 \mathrm{~mL}$ total volume with $\mathrm{H}_{2} \mathrm{O}$, then subjected to centrifugation at $400 \mathrm{~g}$ for $1 \mathrm{~min}$. The $\mathrm{H}_{2} \mathrm{O}$ was decanted, and the solid was resuspended in $10 \mathrm{~mL}$ of $\mathrm{H}_{2} \mathrm{O}$. The process was repeated until the $\mathrm{pH}$ was neutral, then the wet solid was taken up in methanol and concentrated in vacuo to a white solid. This was washed with ether to remove a trace of remaining mineral oil to give $71 \mathrm{mg}(53 \%)$ of a white solid. $\mathrm{mp}>310{ }^{\circ} \mathrm{C}{ }^{1} \mathrm{H}$ NMR $\left(300 \mathrm{MHz}, \mathrm{DMSO}-d_{6}\right) \delta 13.96(\mathrm{~s}, 1 \mathrm{H}), 8.08(\mathrm{~m}, 2 \mathrm{H}), 7.73$ $(\mathrm{m}, 2 \mathrm{H}), 3.50(\mathrm{~s}, 3 \mathrm{H}), 3.27(\mathrm{~s}, 3 \mathrm{H})$; MS $(\mathrm{ESI})^{+} \mathrm{m} / \mathrm{z}=336(\mathrm{M}+\mathrm{H})^{+}$. Anal. Calc'd for $\mathrm{C}_{13} \mathrm{H}_{11} \mathrm{BrN}_{4} \mathrm{O}_{2}$ : C, 46.59; H, 3.31; N, 16.72. Found: C, 46.56; H, 3.09; N, 16.53.<smiles>N/C(=N\c1ncc(Br)cc1Br)c1ccccc1</smiles>

$N$-(3,5-Dibromo-pyridin-2-yl)-benzamidine. To $1.00 \mathrm{~g}(4.00 \mathrm{mmol})$ of 2-amino-3,5dibromopyridine was added $0.9 \mathrm{~mL}$ of benzonitrile, and $1.0 \mathrm{~g}$ of $\mathrm{AlCl}_{3}$. The reaction was heated at $180^{\circ} \mathrm{C}$ for $16 \mathrm{~h}$, then cooled and diluted with $50 \mathrm{~mL}$ of $1 \mathrm{M} \mathrm{NaOH}$ (aq.). The white suspension was extracted with ethyl acetate $(3 \times 20 \mathrm{~mL})$, then the combined ethyl acetate layers were back extracted with $1 \mathrm{M} \mathrm{NaOH}(1 \times 10 \mathrm{~mL})$, and brine $(1 \times 10 \mathrm{~mL})$, dried over $\mathrm{MgSO}_{4}$, filtered, and concentrated to an oil. This was triturated with 9: 1 hexanes: ethyl acetate to give 236 of a solid. The supernatant was then concentrated and the residue was purified via silica gel chromatography, eluting with 85: 15 hexanes: ethyl acetate to give $696 \mathrm{mg}$ of a yellow solid for a total yield of $932 \mathrm{mg}(66 \%)$. The product can also be recrystallized from $\mathrm{CH}_{3} \mathrm{CN}$. mp 126-127 ${ }^{\circ} \mathrm{C} .{ }^{1} \mathrm{H}$ NMR $\left(300 \mathrm{MHz}\right.$, DMSO- $\left.d_{6}\right)$ $\delta 8.99$ (bs, $2 \mathrm{H}), 8.42$ (d, J=2.4 Hz, $1 \mathrm{H}), 8.30$ (d, J=2.4 Hz, $1 \mathrm{H}), 8.12$ (m, $2 \mathrm{H}), 7.51$ (m, $3 \mathrm{H}) ; \mathrm{MS}(\mathrm{ESI})^{+} \mathrm{m} / z=356(\mathrm{M}+\mathrm{H})^{+}$. Anal. Calc'd for $\mathrm{C}_{12} \mathrm{H}_{9} \mathrm{Br}_{2} \mathrm{~N}_{3}$ : C, 40.60; H, 2.56; N, 11.84. Found: $\mathrm{C}, 40.71 ; \mathrm{H}, 2.31 ; \mathrm{N}, 11.70$.<smiles>Brc1cnc2nc(-c3ccccc3)[nH]c2c1</smiles>

6-Bromo-2-phenyl-1H-imidazo[4,5-b]pyridine. To a solution of $355 \mathrm{mg}(1.00 \mathrm{mmol})$ of $N$-(3,5-dibromo-pyridin-2-yl)-benzamidine in $10 \mathrm{~mL}$ of dioxane was added $120 \mathrm{mg}$ (3.00 mmol) of $60 \% \mathrm{NaH}$ in mineral oil, and $10 \mathrm{mg}(0.053 \mathrm{mmol})$ of $\mathrm{CuI}$. The reaction was heated at reflux for $40 \mathrm{~min}$, then $2 \mathrm{~mL}$ of $\mathrm{H}_{2} \mathrm{O}$ was added, and the solvents were removed in vacuo. The residue was suspended in $5 \mathrm{~mL}$ of saturated $\mathrm{NaHCO}_{3(a q \text {.) }}$, then 10 $\mathrm{mL}$ of $1 \mathrm{M} \mathrm{HCl}$ was added to give a precipitate. This was collected, washed with water (3 x $5 \mathrm{~mL})$, and diethyl ether ( $3 \times 3 \mathrm{~mL}), 15 \mathrm{M} \mathrm{NH}_{4} \mathrm{OH}(1 \times 3 \mathrm{~mL})$, and water $(3 \times 5 \mathrm{~mL})$ to give $199 \mathrm{mg}(73 \%)$ of the product. $\mathrm{mp}>310^{\circ} \mathrm{C} .{ }^{1} \mathrm{H}$ NMR $\left(300 \mathrm{MHz}, \mathrm{DMSO}-d_{6}\right) \delta 13.72$ 
(bs, $1 \mathrm{H}), 8.43(\mathrm{~d}, J=1.7 \mathrm{~Hz}, 1 \mathrm{H}), 8.31(\mathrm{~m}, 1 \mathrm{H}), 8.23(\mathrm{~m}, 2 \mathrm{H}), 7.59(\mathrm{~m}, 3 \mathrm{H})$; MS (ESI) ${ }^{+}$ $m / z=274(\mathrm{M}+\mathrm{H})^{+}, 276(\mathrm{M}+\mathrm{H})^{+}$. Anal. Calc'd for $\mathrm{C}_{12} \mathrm{H}_{8} \mathrm{BrN}_{3}: \mathrm{C}, 52.58 ; \mathrm{H}, 2.94 ; \mathrm{N}$, 15.33. Found: N, 52.27; H, 2.66; N, 15.14 .<smiles>CCCC(=N)Nc1ccccc1Br</smiles>

$N$-(2-Bromo-phenyl)-butyramidine. To $1.00 \mathrm{~g}(4.80 \mathrm{mmol})$ of 2-bromoaniline hydrochloride in a sealable tube suitable for microwave heating was added $4 \mathrm{~mL}$ of butyronitrile. The reaction was heated at $180^{\circ} \mathrm{C}$ for $10 \mathrm{~min}$ using a microwave apparatus, then concentrated in vacuo. The residue was taken up in $5 \mathrm{~mL}$ of $2 \mathrm{M} \mathrm{NaOH}$, and extracted with ether $(3 \times 5 \mathrm{~mL})$. The combined ether layers were back extracted with brine ( $1 \times 5 \mathrm{~mL}$ ), dried over $\mathrm{MgSO}_{4}$, filtered, and concentrated to an oil. This was purified via silica gel chromatography, eluting with 50: 50: 0.9: 0.1 ethyl acetate: hexanes: methanol: $15 \mathrm{M} \mathrm{NH}_{4} \mathrm{OH}$, then stepping to $95: 4.5: 0.5$ ethyl acetate: methanol: $15 \mathrm{M} \mathrm{NH}_{4} \mathrm{OH}$ to recover $440 \mathrm{mg}$ ( $\left.38 \%\right)$ of a pale yellow oil. ${ }^{1} \mathrm{H}$ NMR $(300 \mathrm{MHz}$, DMSO$\left.d_{6}\right)$ mixture of rotamers $\delta 7.51(\mathrm{~d}, J=7.8 \mathrm{~Hz}, 1 \mathrm{H}), 7.22(\mathrm{t}, J=7.5 \mathrm{~Hz}, 1 \mathrm{H}), 6.83(\mathrm{t}, J=7.5$ $\mathrm{Hz}, 1 \mathrm{H}), 6.76(\mathrm{~d}, J=7.5 \mathrm{~Hz}, 1 \mathrm{H}), 5.81(\mathrm{~s}, 2 \mathrm{H}), 2.15(\mathrm{~m}, 2 \mathrm{H}), 1.67(\mathrm{~m}, 2 \mathrm{H}), 0.97(\mathrm{~m}, 3$ $\mathrm{H}) ; \mathrm{MS}(\mathrm{ESI})^{+} \mathrm{m} / z=241(\mathrm{M}+\mathrm{H})^{+}, 243(\mathrm{M}+\mathrm{H})^{+}$. Anal Calc'd for $\mathrm{C}_{10} \mathrm{H}_{13} \mathrm{BrN}_{2}: \mathrm{C}, 49.81$; $\mathrm{H}, 5.43$; N, 11.62. Found: C, 49.63; H, 5.54; N, 11.60 .<smiles>CCCc1nc2ccccc2[nH]1</smiles>

2-Propyl-1H-benzoimidazole. To a solution of $241 \mathrm{mg}(1.00 \mathrm{mmol})$ of amidine $\mathrm{xx}$ in 5 $\mathrm{mL}$ of dioxane in a sealable tube suitable for microwave heating was added $200 \mathrm{mg}(5.00$ $\mathrm{mmol})$ of $60 \% \mathrm{NaH}$ in mineral oil, and $10 \mathrm{mg}(0.053 \mathrm{mmol})$ of CuI. The reaction was heated at $150^{\circ} \mathrm{C}$ for $10 \mathrm{~min}$ using a microwave apparatus. After cooling, $2 \mathrm{~mL}$ of $\mathrm{H}_{2} \mathrm{O}$ was added, and the mixture was concentrated in vacuo. The residue was taken up in 5 $\mathrm{mL}$ of $\mathrm{H}_{2} \mathrm{O}$ and extracted with ethyl acetate $(2 \times 5 \mathrm{~mL})$. The combined ethyl acetate layers were back extracted with $5 \mathrm{~mL}$ of brine, dried over $\mathrm{MgSO}_{4}$, filtered, and concentrated in vacuo to a solid. The residue was purified via silica gel chromatography, eluting with ethyl acetate to give $59 \mathrm{mg}(37 \%)$ of a solid. Spectral data were in agreement with those previously reported. ${ }^{7}$

\footnotetext{
${ }^{1}$ Bernatowicz, M. S.; Wu, Y.; Matsueda, G. R. J. Org. Chem. 1992, 57, 2497.

${ }^{2}$ Yamasaki, T.; Kawaminami, E.; Yamada, T.; Okawara, T.; Furukawa, M. J. Chem. Soc. Perkin Trans. 1 1991, 5, 991.

${ }^{3}$ Katritsky, A. R.; Rogovoy, B. V.; Chassaing, C.; Vvedensky, V. J. Org. Chem. 2000, 65, 8080.

${ }^{4}$ Chesterfield, J.; McOmie, J. F. W.; Sayer, E. R. J. Chem. Soc. 1955, 3478. 5-bromo-4,6dichloropyrimidine prepared by this method contained varying amounts of 4,5,6-trichloropyrimidine.

${ }^{5}$ Szilágyi, G.; Wamhoff, H. Synthesis 1981, 701.

${ }^{6}$ Hirota, K.; Sako, M.; Sajiki, H. Heterocycles 1997, 46, 547. The water peak was misassigned as a $\mathrm{CH}_{3}$ peak in the ${ }^{1} \mathrm{H}$ NMR spectrum.

${ }^{7}$ Hay, J. V.; Portlock, D. E.; Wolfe, J. F. J. Org. Chem. 1973, 38, 4379.
} 